\title{
T-2 toxin-induced apoptosis in the mouse lymphoid and hematopoietic tissues
}

\author{
Junko SHINOZUKA ${ }^{* 1,2}$ and Kunio DoI ${ }^{* 1}$ \\ ${ }^{* 1}$ Department of Veterinary Pathology, Graduate School of Agricultural and Life Sciences, The University of Tokyo \\ (1-1-1 Yayoi, Bunkyo-ku, Tokyo 113-8657, Japan) \\ ${ }^{* 2}$ Exploratory Toxicology and DM PK Research Laboratories, Tanabe Seiyaku Co., Ltd. \\ (2-2-50 Kawagishi, Toda-shi, Saitama 335-8505, Japan)
}

\begin{abstract}
Summary
To clarify the characteristics and mechanisms of T-2 toxin-induced cell death in the lymphoid and hematopoietic tissues, in vivo and in vitro studies were carried out. As a result, $\mathrm{T}-2$ toxin-induced lesions in the thymus, spleen and bone marrow of mice were shown to be brought about by apoptosis of component cells. The sequence of T-2 toxin-induced apoptosis varied among tissues, and apoptosis was occurred earlier in the hematopoietic tissues than in the lymphoid tissues. By RT-PCR method, the expression of c-fos mRNA increased immediately after $\mathrm{T}-2$ toxin-inoculation and remained high levels throughout the observation period. Cycloheximide, a protein synthesis inhibitor, blocked apoptosis in the thymus of T-2 toxin-inoculated mice. As observed in in vivo study, in Con A-stimulated mouse thymocyte cultures, T-2 toxin induced the elevation of c-fos mRNA expression prior to the development of apoptosis. BAPTA/AM and Quin-2/AM, intracellular calcium chelators, and $\mathrm{H}-7$, a PKC inhibitor, blocked the increase in the level of c-fos mRNA expression after T-2 toxin-treatment. These intracellular calcium chelators also inhibited DNA fragmentation after T-2 toxintreatment. These results suggest that T-2 toxin attacks cells with high proliferating activity such as lymphoid and hematopoietic cells, c-fos gene plays an important role in the early phase of T-2 toxin-induced apoptotic cell death probably through sythesis of a certain protein such as heat shock protein, and the elevation of c-fos mRNA expression may require the mobilization of $\left[\mathrm{Ca}^{2+}\right] \mathrm{i}$ and partially involve a PKC-dependent pathway. The mobilization of $\left[\mathrm{Ca}^{2+}\right]$ i seemed to activate calcium-dependent enzymes, resulting in internucleosomal DNA fragmentation.
\end{abstract}

Key words : T-2 toxin, apoptosis, thymus, spleen, bone marrow

(Received: April 23, 2003)

T-2 toxin is a cytotoxic fungal secondary metabolite, produced by various species of Fusarium, which infect corn, wheat, barley and rice crops in the field or during storage ${ }^{1,22}$. T-2 toxin is a kind of sesquiterpenoid fungal metabolites, called trichothecenes, whose common skeleton includes double bond between carbon atoms 9 and 10, and an epoxide group at carbons C -12 and $13^{3)}$. The chemical structure of T-2 toxin was elucidated in 1968 by Bamburg et al. ${ }^{4)}$ and shown to be 3a-hydroxy-4b, 15diacetoxy-8a-(3-methylbutyryloxy)-12, 13-epoxytrichothec-9-ene (Fig. 1).

Fusarium spp. can affect human and farm animals by producing either mycotoxicosis or invasive disease. Overt clinical signs and effects of acute and subacute trichothecene toxicosis have been 


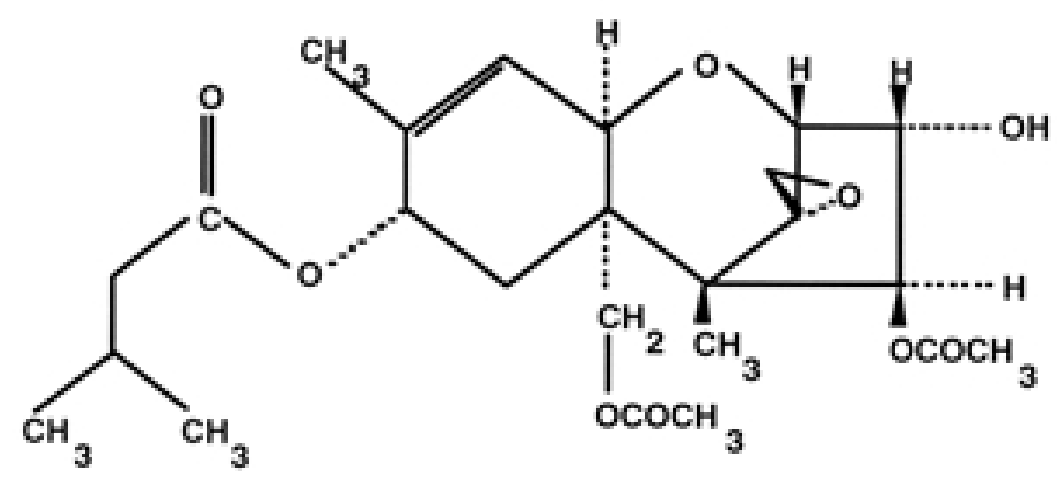

Fig. 1. The structure of T-2 toxin.

reported in naturally occurring cases. A disease known as "alimentary toxic aleukia" in humans is characterized by leukopenia, agranulocytosis, hemorrhagic diathesis, bone marrow aplasia and sepsis, and caused the death of hundreds of thousands of people in Seberia in USSR during the World War $1 \mathrm{I}^{5}$. This disease was caused by consumption of T-2 toxin-contaminated grains ${ }^{6)}$. The toxic effects of T-2 toxin have been studied in experimental animals $\mathrm{s}^{7-12)}$, poultr $\mathrm{y}^{13-15)}$, ducks ${ }^{16)}$, cattl $\mathrm{e}^{17)}$, sheep ${ }^{18)}$, and swine ${ }^{19,20)}$. All animal species tested appeared to be sensitive to this mycotoxin. Oral, parenteral and cutaneous exposures of trichothecene mycotoxin produced lesions in hematopoietic, lymphoid and gastrointestinal tissues and functional suppression of reproductive organs ${ }^{21-24)}$. Experimental injection of T-2 toxin to rats resulted in cardiomyopathy ${ }^{25)}$. Signs somewhat similar to those in human alimentary toxic aleukia were observed in rhesus monkeys and cats fed T-2 toxin ${ }^{26)}$.

Trichothecenes are reported to have inhibitory activities against protein and DNA synthesis ${ }^{27}$. However, the exact mechanisms of T-2 toxin-induced cell death still remain unknown. In this regard, Quiroga et al. ${ }^{28)}$ in our research group reported the ultrastructural changes of thymocytes suggesting apoptotic cell death in T-2 toxin-inoculated mice. Our subsequent examinations first clarified from the multiple viewpoints that T-2 toxin-induced lesions were characterized as apoptosis. This review described the characteristics and mechanisms of T-2 toxin-induced cell death in the lymphoid and hematopoietic tissues of mice.

\section{Characteristics of T-2 toxin-induced cell death in the lymphoid tissues}

$\mathrm{T}-2$ toxin-induced lesions in the thymus and splenic lymphoid follicles were examined up to 48 hours after oral inoculation of $10 \mathrm{mg} / \mathrm{kg}$ b.w. of T-2 toxin in ICR:CD-1 female mice ${ }^{29)}$. The body weight gain and the relative organ weights of the thymus and spleen decreased time-dependently in T-2 toxintreated animals. Histopathologically, narrowing of thymic cortex and atrophy of splenic lymphoid follicles due to a decrease in the number of lymphocytes were observed. Such decrease in the number of lymphocytes was considered to be brought about by cell death, and dead cells were histopathologically characterized by pyknosis or karyorrhexis, and the nuclei of these cells were strongly stained by the modified TUNEL method that is widely used to detect fragmented DNA in 
situ (Fig. 2a). Electron microscopically, the dead cells were characterized by shrinkage of the cell body and condensation of nuclear chromatin frequently along the nuclear membrane, and such nuclei were sometimes fragmented into small pieces (Figs. $2 b$ and $2 c$ ). These morphological characteristics of dead lymphocytes were well consistent with those of apoptosis ${ }^{30,31)}$. In the thymus, epithelial cells with aggregated intracytoplasmic cysts containing a few microvilli were also detected (Fig. 2d). Such

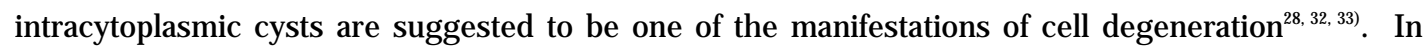
addition to these morphological findings, DNA ladder was detected by agarose gel electrophoresis using DNA samples extracted from the thymus (Fig. 2e). The above-mentioned findings of morphology and agarose gel electrophoresis clearly indicate that T-2 toxin induces apoptotic cell death in the lymphoid tissues of mice.

The lymphocyte changes started earlier and were more severe in the thymus than in the splenic lymphoid follicles. This suggests that the lymphocyte population susceptible to T-2 toxin may be larger in the thymus than in the splenic lymphoid follicles, and there may be a relationship between lymphocyte maturation and its susceptibility to T-2 toxin. The number of proliferating cell nuclear antigen (PCNA)- positive lymphocytes which are in the dividing cell cycle ${ }^{34)}$ decreased prior to the progression of apoptotic cell death in the thymus and splenic lymphoid follicles in T-2 toxin-treated animals. In this connection, the number of PCNA-positive lymphocytes were prominently larger in the thymus than in the splenic lymphoid follicles in control animals. Such difference in PCNA-positive lymphocyte population may also be related to the difference in the susceptibility to T-2 toxin between these two lymphoid tissues.

\section{Characteristics of T-2 toxin-induced cell death in the hematopoietic tissues}

$\mathrm{T}-2$ toxin-induced lesions in the bone marrow and splenic red pulp were examined up to 48 hours after oral inoculation of $10 \mathrm{mg} / \mathrm{kg}$ b.w. of T-2 toxin in ICR:CD-1 female mice ${ }^{35}$. Significant depression in the numbers of white blood cells and platelets were observed in the peripheral blood of T-2 toxintreated animals. T-2 toxin induced a significant hypocellularity in the bone marrow and splenic red pulp as well as in the thymus, and these damages in multiple hematopoietic compartments resulted in the decrease in the number of lymphocytes in the periphery of treated animals (Fig. 3), and it is reasonable to consider that changes in peripheral blood may reflect the hypocellularity in both lymphoid and hematopoietic tissues. Bone marrow analysis using smears indicated that the decrease in the number of myelocytes was due to loss of granulocytes, erythroblasts and lymphocytes, and granulocytes and erythroblasts decreased earlier than lymphocytes (Fig. 4). On the other hand, mature granulocytes showed no significant changes throughout the observation period. In addition, the number of PCNA-positive myelocytes decreased in T-2 toxin-treated animals, suggesting that T-2 toxin affects immature myelocytes with high mitotic activity.

In the bone marrow, myelocytes showed characteristics of apoptosis, and T-2 toxin-induced apoptosis was detected earlier in the bone marrow than in the lymphoid tissues. The spleen, which is composed of white and red pulps, is the largest lymphoid tissue in the circulation, and it is the site of erythrocyte storage and removal of dysfunctioned erythrocytes and leukocytes. In addition, it is well known that rodents have hematopoietic activity in the red pulp regardless of age $\mathrm{e}^{36)}$. In T-2 toxin- 

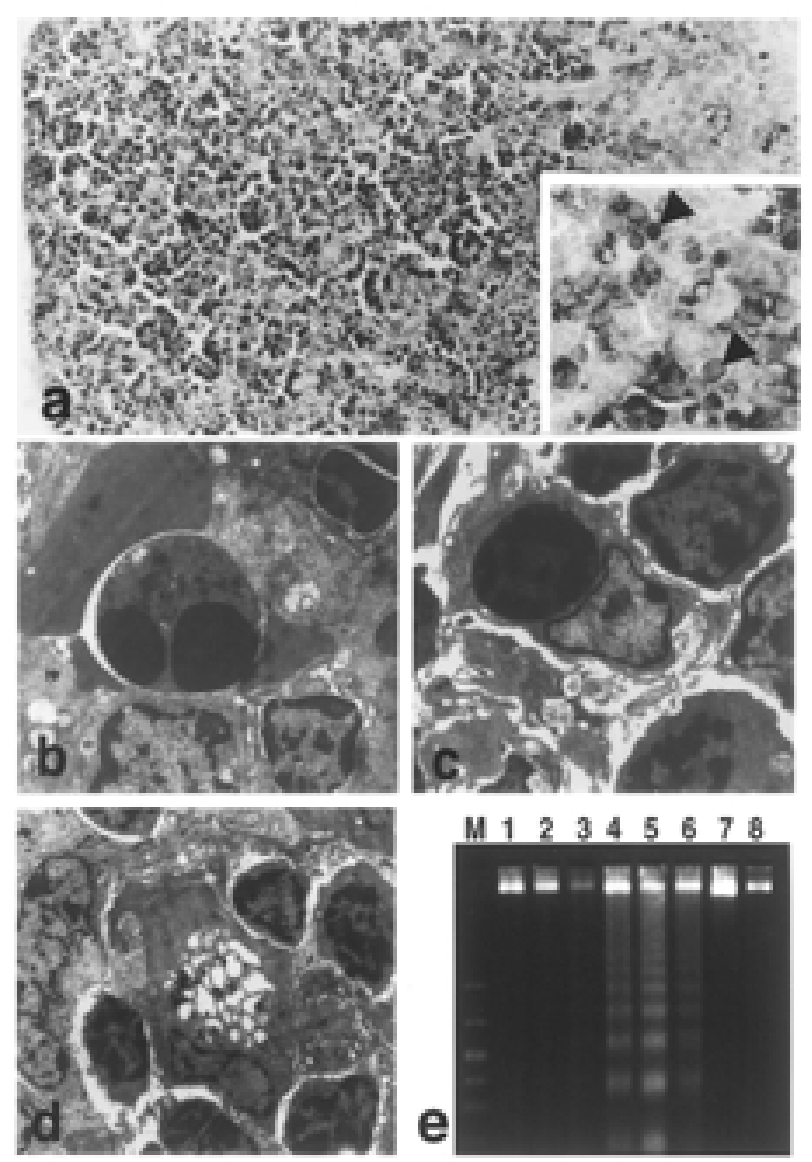

Fig. 2. Characterization of T-2 toxin-induced apoptosis.

a) Thymus of a female ICR: CD-1 mouse at 24 hours after inoculation (HAI) with 10 $\mathrm{mg} / \mathrm{kg}$ of $\mathrm{T}-2$ toxin. A large number of lymphocyte nuclei are positively stained (arrowheads) by the modified TUNEL method. TUNEL, x 150. Inset, x 600 .

b-d) Electron micrographs of thymus in a female ICR: CD-1 mouse inoculated with 10 $\mathrm{mg} / \mathrm{kg}$ of T-2 toxin. Nuclear chromatin condensation and fragmentation of lymphocytes ( $6 \mathrm{HAl})$ (b), some of which are ingestied by adjacent epithelial cells or macrophage $(6 \mathrm{HAI})(\mathrm{c})$. E pithelial cell with aggregated intracytoplasmic cysts in medulla (24 HAI) (d). b, c: $x 4000$. d: $x 2500$.

e) Agarose gel electrophoresis of DNA extracted from the thymus of a female ICR: CD-1 mouse inoculated with $10 \mathrm{mg} / \mathrm{kg}$ of T-2 toxin. DNA ladder formation first appears at $9 \mathrm{HAl}$ (lane 4), and becomes clearer at, 12 (lane 5) and 24 (lane 6). At $48 \mathrm{HAl}$ (lane 7), it becomes Indistinct. Lane M: low maker, Lane 1: $1 \mathrm{HAI}$, Lane 2: $3 \mathrm{HAl}$. lane 3: $6 \mathrm{HAI}$, lane 8: Control.

treated mice, the red pulp showed a significant hypocellularity prior to the development of atrophy of the splenic lymphoid follicles, and the time of onset of significant hypocellularity due to component cell apoptosis was similar between the bone marrow and the splenic red pulp. Thus, T-2 toxininduced lesions were brought about by apoptosis of component cells in both lymphoid and hematopoietic tissues, and hematopoietic cell apoptosis occurred earlier than lymphoid cell apoptosis. In addition to the above-mentioned tissues, T-2 toxin induced apoptosis of lymphocytes in the 


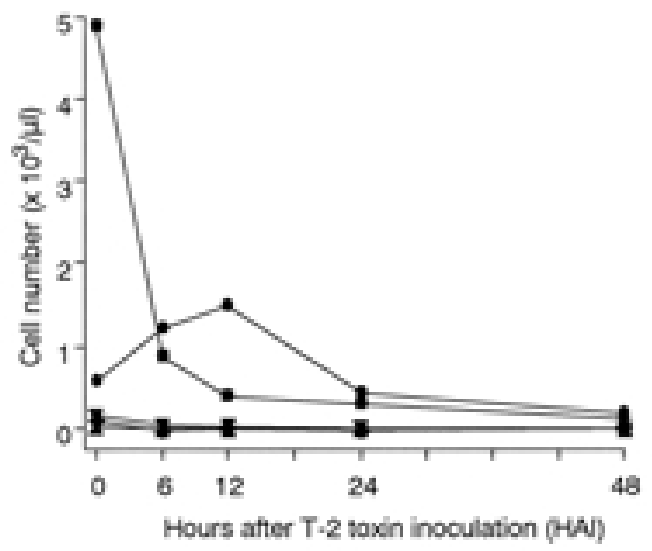

Fig. 3. Sequential changes of differential leucocyte counts in peripheral blood after T-2 toxin inoculation. : neutrophil; $\diamond$ : eosinophil; $\boldsymbol{\Delta}$ : basophil; $\boldsymbol{\nabla}$ : monocyte; $\boldsymbol{\square}$ : lymphocyte. Numbers represent mean of 4 animals per group.

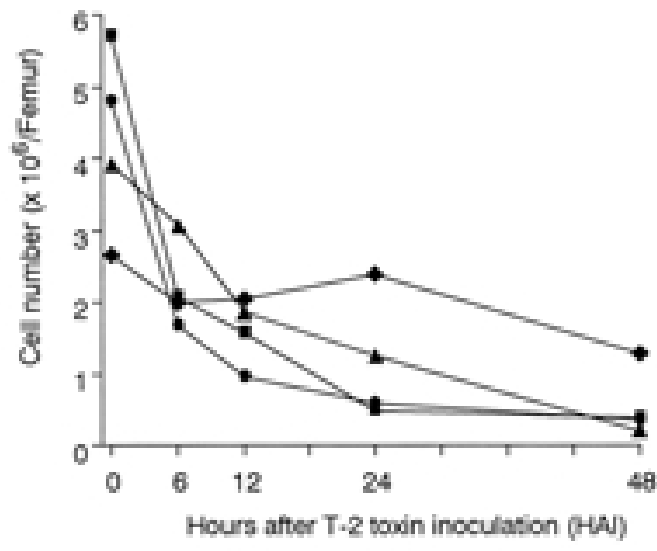

Fig. 4. Sequential changes in differential myelocyte values in the femur of mice after T-2 toxininoculation. $\mathbf{\square}$ : immature granulocyte series; $\boldsymbol{\bullet}$ : mature granulocyte series; $\mathbf{O}$ : erythroid series ; $\boldsymbol{\Delta}$ : lymphocyte. Numbers represent mean of 4 animals per group.

Peyer's patches ${ }^{37)}$ and mesenteric lymph nodes ${ }^{38)}$, intestinal crypt epithelial cells of mice ${ }^{39)}$, developing mouse embryos ${ }^{40,41)}$ and epidermal cells in the dorsal skin of WBN/ ILA-H t rats ${ }^{42-44)}$.

\section{Kinetics of apoptosis-related gene expression}

Gene expression prior to the development of apoptosis has been investigated in various cell types, and it has been clarified that some proto-oncogenes called apoptosis-related genes regulate the induction and/ or inhibition of apoptosis ${ }^{45-47}$. Gene induction during apoptosis has been investigated in the lymphoid tissues, and it has been clarified that some cell surface antigens and proto-oncogenes regulate the induction of apoptosis. In our study, the level of c-fos mRNA expression in the thymus of T-2 toxin-inoculated mice significantly increased prior to the development of apoptosis, while the levels of Fas, p53, bcl-2 and c-myc mRNAs expression showed no significant changes throughout the observation period (Fig. 5) ${ }^{48}$. In addition, T-2 toxin induced apoptotic cell death in the lymphoid tissues of both p53 -knockout mice and Fas-disfunctional mice (Ipr/lpr mutant mice). These results indicate that $\mathrm{p} 53$ and $\mathrm{F}$ as antigen have no relation to $\mathrm{T}-2$ toxin-induced lymphocyte apoptosis. Taken together, the induction of c-fos mRNA is considered to be associated with T-2 toxin-induced apoptosis. The c-fos proto-oncogene is a kind of immediate-early response genes (IEGs). The activation of specific genes including IEGs such as c-fos, c-jun and c-myc is one of the early responses to acute cell injury ${ }^{49,50)}$, and such modified gene expression may be involved in the activation of subsequent responses, including cell proliferation and/or differentiation ${ }^{51)}$ as well as activation of other genes ${ }^{52)}$. Several studies reported that the expression of c-fos mRNA preceded the initiation of apoptosis or it was concomitant with apoptosis in many systems ${ }^{53-56}$. Preston et al. ${ }^{57)}$ reported that the c-Fos protein induced apoptosis in sup-II preneoplastic cells in serum-free medium. In addition, they showed that c-Fos-induced apoptosis in their system was not blocked by cycloheximide, a protein inhibitor, 

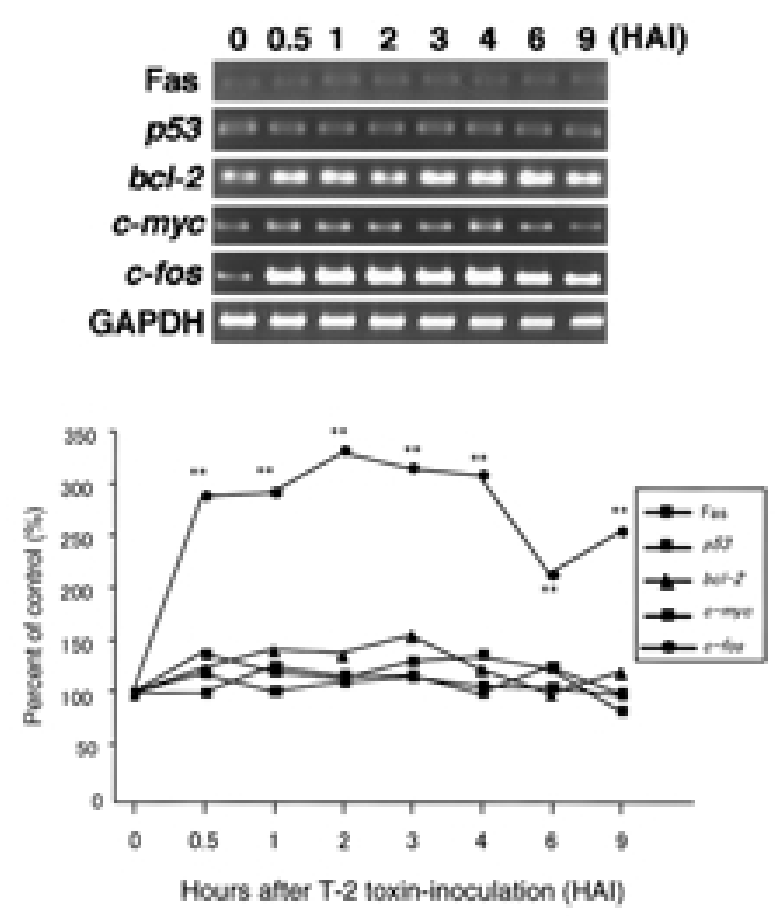

Fig. 5. Sequential changes in mRNA expressions of Fas and apoptosis-related genes in the thymus of mice after T-2 toxin-inoculation. Each value (mean of 5 animals per group) represents relative ratio to GAPDH. * $\mathrm{p} \varangle 0.05,{ }^{* *} \mathrm{p} \varangle 0.01$ : Significantly different from control $(0 \mathrm{HAI})$.

suggesting that the transcriptional activation of c-fos gene is not involved in apoptosis of sup- II preneoplastic cells. On the other hand, in our study, cycloheximide inhibited apoptosis in the thymus of T-2 toxin-inoculated mice in our study ${ }^{48)}$, suggesting that c-fos induction may have an important regulatory role in the process of T-2 toxin-induced apoptosis in the lymphoid and hematopoietic tissues probably through apoptosis-related protein synthesis. The precise mechanism of the inhibitory effect of cycloheximide on T-2 toxin-induced apoptosis remains obscure, because T-2 toxin itself has an inhibitory effect on protein synthesis.

\section{Effects of calcium chelators and PKC inhibitors on T-2 toxin-induced apoptosis and c-fos mRNA expression in thymocyte primary cultures}

T-2 toxin also induced apoptotic cell death in ConA-stimulated mouse thymocyte primary cultures $^{58)}$. Cell viability significantly decreased when the level of fragmented DNA increased in ConAstimulated mouse thymocyte primary cultures treated with $0.2 \mu \mathrm{g} / \mathrm{ml}$ of $\mathrm{T}-2$ toxin (Fig. 6). In addition, a rapid and continuous increase in the expression of c-fos mRNA was observed prior to the development of apoptotic cell death in this system after T-2 toxin-treatment (Fig. 7). The regulatory mechanisms underlying transcription of c-fos have been studied extensively, and it is well established that both [ $\left.\mathrm{Ca}^{2+}\right] \mathrm{i}$ mobilization and PKC activation lead to an accumulation of this transcript ${ }^{59-61)}$. There are substantial evidences that the regulation of c-fos expression involves the major intracellular 


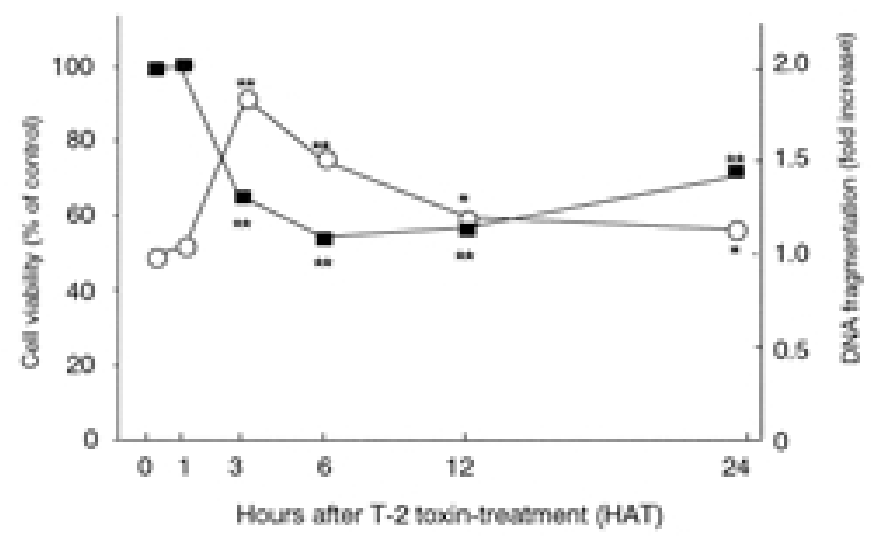

Fig. 6. Effect of T-2 toxin on cell viability ( $\boldsymbol{\square}$ ) and DNA fragmentation ( $\bigcirc$ ). Con A-stimulated mouse thymocytes were incubated with $0.2 \mu \mathrm{g} / \mathrm{ml}$ of T-2 toxin for up to 24 HAT. DNA fragmentation was examined on thymocytes by ELISA method (Cell Death Detection ELISA; Boehringer M annheim GmbH, Germany). Each value represents the mean of 4 samples per groups. $* p \varangle 0.05, * * p \varangle 0.01$ : Significantly different from control.
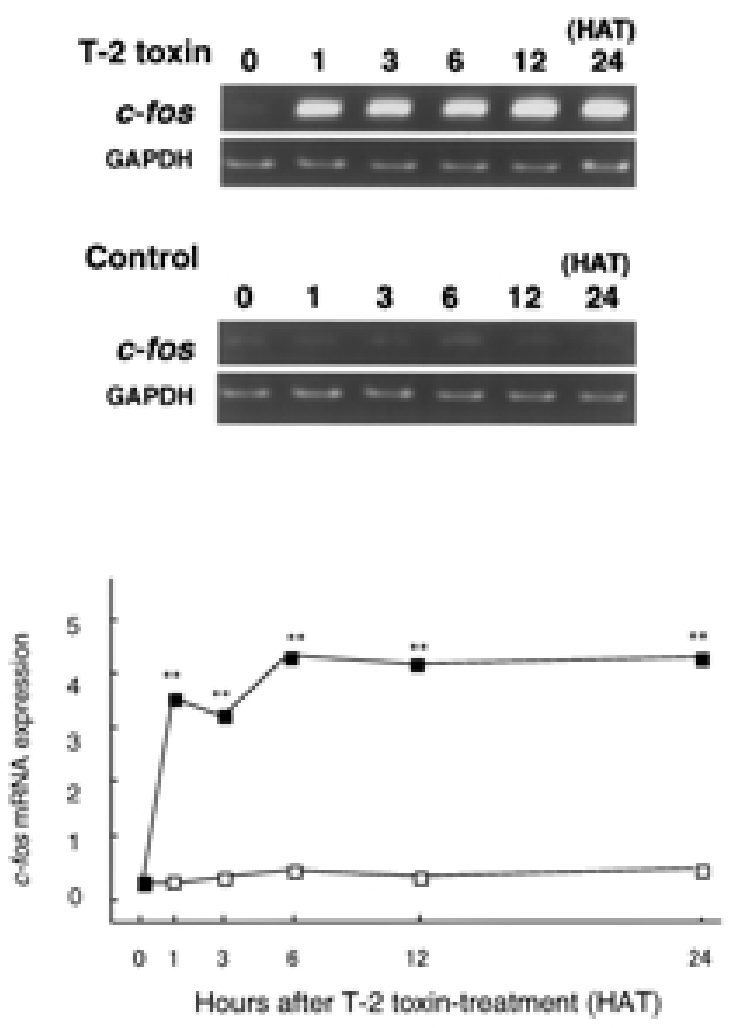

Fig. 7. Sequential changes of c-fos mRNA expression in Con A-stimulated mouse thymocytes. Con A-stimulated mouse thymocyes were incubated with $0.2 \mu \mathrm{g} / \mathrm{ml} \mathrm{T}-2$ toxin or solvent alone (control) for up to 24 hours. Con A-stimulated mouse thymocyes were incubated with 0.2 $\mu \mathrm{g} / \mathrm{ml} \mathrm{T}-2$ toxin ( $\boldsymbol{\square}$ ) or solvent alone ( $\square$ ) for up to 24 hours. Each value represents the mean of 4 samples per group. ${ }^{* *} p \varangle 0.01$ : Significantly different from control. 
second messenger, $\mathrm{Ca}^{2+60)}$. In our study, the induction of c-fos was suppressed by chelation of intracellular ionized calcium ([ $\left.\mathrm{Ca}^{2+}\right]$ i) by BAPTA/ AM and Quin 2/ AM, intracellular calcium chelators,

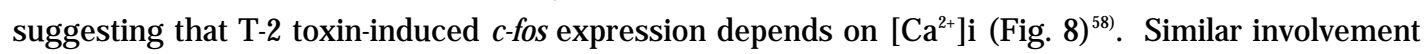
of $\left[\mathrm{Ca}^{2+}\right] \mathrm{i}$ has been reported in the induction of $\mathrm{c}$-fos after oxidative stress ${ }^{62)}$ and of hsp70 after heat shock ${ }^{63)}$. Although the effect of $\mathrm{T}-2$ toxin on [ $\left.\mathrm{Ca}^{2+}\right]$ i remains obscure, Yoshino et al. ${ }^{64)}$ reported that the level of $\left[\mathrm{Ca}^{2+}\right] \mathrm{i}$ was markedly elevated in $\mathrm{HL}-60$ cells after exposure to T-2 toxin. They also reported that intracellular calcium chelators inhibited T-2 toxin-induced apoptosis in HL-60 cells. In our study, BAPTA/ AM and Quin 2/ AM depressed the increase in the level of fragmented DNA by T-2 toxin. As mentioned above, the mechanism of mobilization of $\left[\mathrm{Ca}^{2+}\right] \mathrm{i}$ is still obscure. However, chelation of an extracellular ionized calcium ([ $\left.\mathrm{Ca}^{2+}\right]$ e) by EGTA had no effect on the expression of c-fos mRNA and the induction of DNA fragmention in mouse thymocyte primary cultures after T-2 toxin-
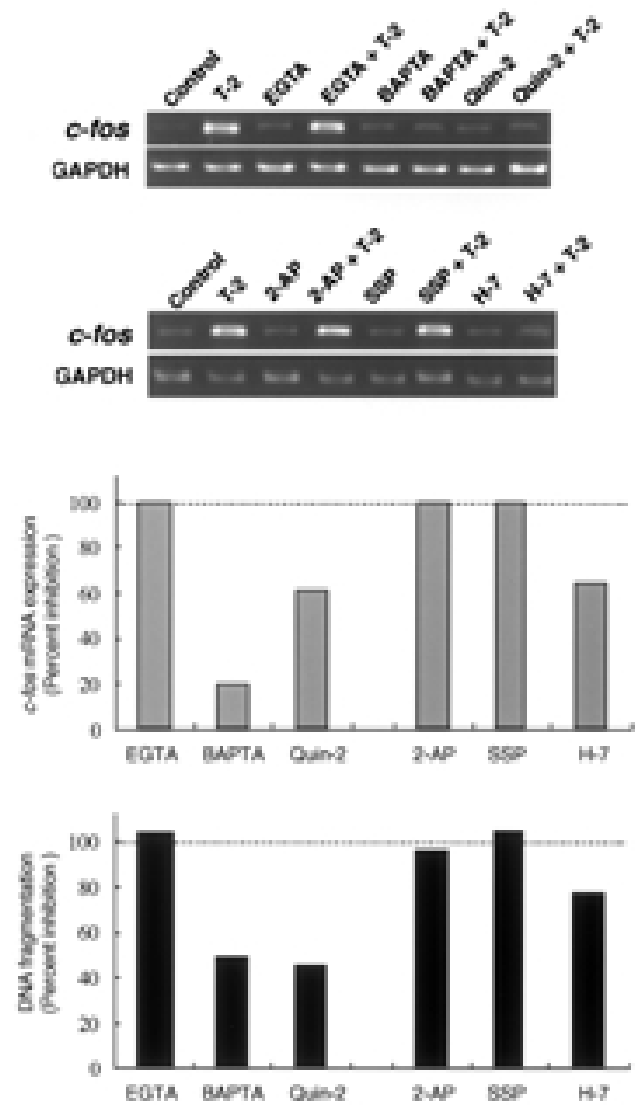

Fig. 8. Inhibition of T-2 toxin-induced c-fos mRNA and DNA fragmentation by calcium chelators and PKC inhibitors in Con A stimulated mouse thymocytes. Cells were preincubated in EGTA (0.1 $\mathrm{mM})$, BAPTA/AM $(25 \mu \mathrm{M})$, Quin-2/AM $(25 \mu \mathrm{M})$, 2-aminopurine (2-AP) (10 mM), staurosporine (SST) $(50 \mathrm{nM})$ or $\mathrm{H}-7(20 \mu \mathrm{M})$, and then incubated with $0.2 \mu \mathrm{g} / \mathrm{ml}$ of T-2 toxin or solvent alone (control) for 1 hour. DNA fragmentation was examined on thymocytes by ELISA method (Cell Death Detection ELISA; Boehringer M annheim GmbH, Germany). c-fos mRNA expression and DNA fragmentation are expressed as the percent inhibition (percent of T-2 toxin alone). Each value represents the mean of 3 samples per group. 
treatment, suggesting that the increase in $\left[\mathrm{Ca}^{2+}\right] \mathrm{i}$ may not be due to the influx of extracellular $\mathrm{Ca}^{2+}$ but may be brought about by the intracytoplasmic release of $\mathrm{Ca}^{2+}$ from endoplasmic reticula. Although less effective as compared with intracellular ionized calcium chelators, H-7, a PKC inhibitor, also showed depressive effects on T-2 toxin-induced c-fos mRNA expression and DNA fragmentation in mouse thymocyte primary cultures (Fig. 8). This suggests that PKC-dependent pathway may be partially involved in T-2 toxin-induced apoptosis.

Based on the above-mentioned results, the hypothesis of the mechanisms of T-2 toxin-induced apoptosis was considered as shown in Fig. 9. Namely, T-2 toxin attacks cells with high proliferating activity such as lymphoid and hematopoietic cells. The c-fos gene probably plays an important role in the early phase of T-2 toxin-induced apoptotic cell death, and the elevation of c-fos mRNA expression may require the mobilization of $\left[\mathrm{Ca}^{2+}\right] \mathrm{i}$ and partially involve a PKC-dependent pathway. The mobilization of $\left[\mathrm{Ca}^{2+}\right] \mathrm{i}$ activates calcium-dependent enzymes, which mediate internucleosomal DNA fragmentation, and the elevation of c-fos expression may affect sythesis of a certain protein such as heat shock protein. Our studies first clarified the apoptotic nature of cell death in mycotoxicosis, and the results of the present study are much informative for further investigations of mycotoxin-induced apoptosis.

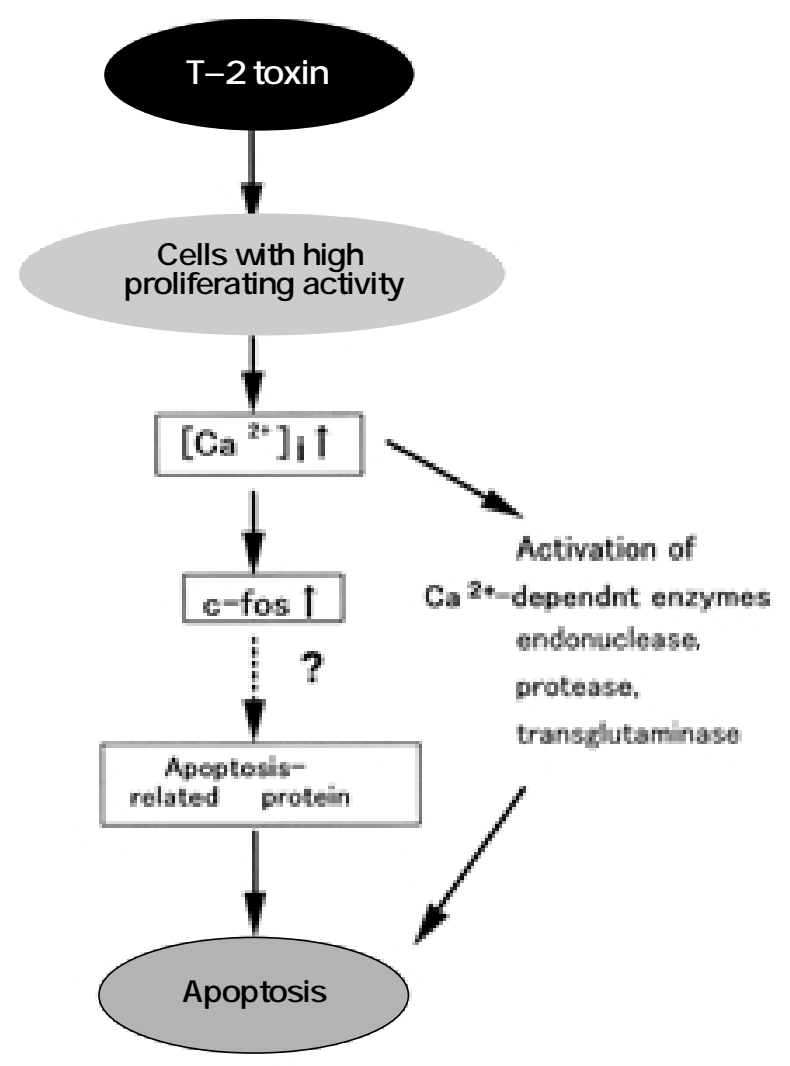

Fig. 9. Hypothesis on mechanism of T-2 toxin-induced apoptosis. 


\section{References}

1 ) Desjardins, A.E., Hohn, T.M ., M cCormick, S.P. : M icrobiol. Rev., 57, 595-604 (1993)

2 ) Nelson, P.E., Dignani, M .C., Anaissie, E.J.: Clinical M icrobiol. Rev., 7, $479-504$ (1994)

3 ) Yagen, B., Bialer, M.: Drug M etabolism Rev., 25, 281-323 (1993)

4 ) Bamburg, J.R., Riggs, N.V., Strong, F.M .: Tetrahedron, 24, 3329-3336 (1968)

5 ) J offie, A.: M ycotoxic Fungi, Mycotoxins and Mycotoxicoses (eds. Wylie, T., Morehouses, L.), pp.21-59 (1978), M arcel Dekker, New York

6 ) Mirocha, C.J., Pathre, S.: Appl. M icrobiol., 26, 719-724 (1973)

7 ) DeNicola, D.B., Rebar, A.H., Carlton, W.W., Yagen, B.: Food \& Cosmet. Toxicol. 16, 601-609 (1978)

8 ) Norppa, H., Penttila, M., Sorsa, M., Hintikka, E.L., Ilus, T.: Hereditas, 93, 329-332 (1980)

9 ) Rukmini, C., Prasad, J.S., Rao, K.: Food \& Cosmetics Toxicology, 18, 267-269 (1980)

10) Hayes, M.A., Schiefer, H.B., J.: Appl. Toxicol., 2, 207-212 (1982)

11) Glavits, R., Vanyi, A., Fekete, S., Tamas, J.: Acta Vet. Hungarica, 37, $75-79$ (1989)

12) M ollenhauer, H.H., Corrier, D.E., Droleskey, R.E.: J. Submicro. Cytol. \& Pathol., 21, 611-617 (1989)

13) Wyatt, R.D., Hamilton, P.B., Burmeister, H.R.: Poultry Sci., 52, $1853-1859$ (1973)

14) Chi, M .S., M irocha, C.J., Kurt, H.J., Weaver, G., Bates, F., Shimoda, W.: Poultry Science, 56, 306-313 (1977)

15) Terao, K., Kera, K., Yazima, T.: Virchows Archiv. B. Cell Pathol., 27, $359-370$ (1978)

16) Hayes, M.A., Wobeser, G.A.: Can. J. Com. M ed., 47, 180-187 (1983)

17) M atthews, J.G., Patterson, D.S., Roberts, B.A., Shreeve B.J.: Vet. Rec., 101, 391 (1977)

18) Friend, S.C., Hancock, D.S., Schiefer, H.B., Babiuk, L.A.: Can. J. Comp. M ed., 47, 291-297 (1983)

19) Weaver, G.A., Kurtz, H.J., Bates, F.Y., Chi, M.S., M irocha, C.J., Behrens, J.C., Robison, T.S.: Vet. Rec., 103, 531-535 (1978)

20) Pang, V.F., Lorenzana, R.M., Beasley, V.R., Buck, W.B., Haschek, W.M.: Fund. Appl. Toxicol., 8, 298-309 (1987)

21) Stanford, G.K., Hood, R.D., Hayes, A.W.: Res. Commun. Chem. Pathol. Pharmacol., 10, 743-746 (1975)

22) Williams, P.P.: Arch. Environ. Contamination \& Toxicol., 18, 374-387(1989)

23) IARC: IARC M onographs on the Evaluation of the Carcinogenic Risk of Chemicals to Humans, (1993), Lyon

24) Sharma, R.P.: J. Dairy Sci., 76, $892-897$ (1993)

25) M agnuson, B.A., Schiefer, H.B., Hancock, D.S., Bhatti, D.S.: Can. J. Physiol. Pharmacol., 65, 799-802 (1987)

26) Lutsky, I., M or, N.: Lab. Anim. Sci., 31, 43-47(1981)

27) Ueno, Y., Nakajima, M., Sakai, K., Ishi, K., Sato, N., Shimada, N.: J. Biochem., 74, 285-296 (1973)

28) Quiroga, M.A., Itagaki, S., Doi, K.: J. Toxicol. Pathol., 6, 109-112 (1993)

29) Shinozuka, J., Guanmin, L., U etsuka, K., Nakayama, H., Doi, K.: Exp. Anim., 46, 117-126 (1997)

30) Kerr, J.F., Wyllie, A.H., Currie, A.P.: Br. J. Cancer, 26, 239-257 (1972)

31) Trump, B.F., Berezesky, I.K., Chang, S.H., Phelpes, P.C.: Toxicol. Pathol., 25, $82-88$ (1997)

32) Ghadially, F.N.: Cytoplasmic matrix and its inclusions, (1988), Butterworth, London

33) Glavits, R., Vanyi, A.: Acta Vet. Hungarica., 36, 37-41 (1988)

34) Preziosi, R., Sarli, G., Benazzi, C., M arcato, P.S.: J. Comp. Pathol., 113, 301-313 (1995)

35) Shinozuka, J., Suzuki, M., Noguchi, N., Sugimoto, T., Uetsuka, K., Nakayama, H., Doi, K.: Toxicol. Pathol., 26(5), 674-681 (1998) 
36) Seifert, M .F., M arks, S.C.: Experimentia, 41, 192-199 (1985)

37) Li, G., Shinozuka, J., U etsuka, K., Nakayama, H., Doi, K.: J. Toxicol. Pathol., 10, 59-61 (1997)

38) Nagata, T., Suzuki, H., Ishigami, N., Shinozuka, J., Uetsuka, K., Nakayama, H., Doi, K.: Exp. Toxic. Pathol, 53, 309-315 (2001)

39) Li, G., Shinozuka, J., Uetsuka, K., Nakayama, H., Doi, K.: Exp. Toxicol. Pathol., 49, 447-450 (1997)

40) Ishigami, N., Shinozuka, J., Katayama, K., Nakayama, H., Doi, K.: Histol. Histopathol., 14, 729-733 (1999)

41) Ishigami, N., Shinozuka, J., Katayama, K., Nakayama, H., Doi, K.: Exp. Toxic. Pathol, 52, 493-501 (2001)

42) Albarenque, S.M., Shinozuka, J., I wamoto, S., K., Nakayama, H., D oi, K.: Histopathol., 14, 337-342 (1999)

43) Albarenque, S.M., Shinozuka, J., Suzuki, K., Nakayama, H., Doi, K.: Exp. Toxic. Pathol, 52, 297-301 (2000)

44) Albarenque, S.M., Suzuki, K., Shinozuka, J., Nakayama, H., Doi, K.: Exp. Toxic. Pathol, 52, 553-556 (2001)

45) Vaux, D.L., Cory, S., Adams, J.: Nature, 335, 440-442 (1988)

46) Clarke, A.R., Purdie, C.A., Harrison, D.J., Morris, R.G., Bird, C.C., Hooper, M.L., Wyllie, A.H.: Nature, 362, 849-852 (1993)

47) Sentman, C.L., Shutter, J.R., Hockenbery, D., Kanagawa, O., Korsmeyer, S.L.: Cell, 67, 879-88 (1992)

48) Shinozuka, J., Tsutsui, S., Ishigami, N., Ueno-Yamnouchi, A., Nakayama, H., Doi, K.: J. Toxicol. Pathol., 12, 77-81 (1999)

49) Verma, I.M., M itchell, R.L., Kruijer, W., Beveren, C.V., Zokas, L., Hunter, T., Cooper, J.A.: Cancer Cells, 3, 275-287 (1985)

50) Lau, L.F., Nathans, D.: Proc. Natl. Acad. Sci. USA, 84, 1182-1186 (1987)

51) Miller, A.D., Curran, T., Verma, I.M .: Cell, 36, 51-60(1984)

52) Herrlich, P., Ponta, H., Stein, B., J onat, C., Gobel, S., Koni, H., Williams, R., Ivanov, V., Rahmsdorf, H.: Transcription factors in normal and malignat cells (ed. Sluyser, M.), pp.150-158 (1990), Ellis Howard Series in Biomedicine, Amsterdam

53) Colotta, F., Polentarutti, N., Sironi, M., M antovani, A.: J. Biol. Chem., 267, 18278-18283 (1992)

54) Smeyne, R.J ., Vendrell, M., Hayward, M., Baker, S.J., M iao, G.G., Schilling, K., Robertson, L.M ., Curran, T., M organ, J.I.: Nature, 363, 166-169 (1993)

55) M arti, A., Jehn, B., Costello, E., Keon, N., Ke, G., M artin, F., Jaggi, R.: Oncogene, 9, 1213-1223 (1994)

56) Mils, V., Piette, J., Barette, C., Veyrune, J., Tesniere, A., Escot, C., Guilhou, J.J., Basset-Seguin, N.: Oncogene, 14, 1555-1561(1997)

57) Preston, G.A., Lyon, T.T., Yin, Y., Lang, J.E., Solomon, G., Annab, L., Srinivasan, D.G., Alcorta, D.A., Barrett, J.C.: Mol. Cell Biol., 16, 211-218 (1996)

58) Shinozuka, J., Suzuki, H., Tsutsui, S., Nakayama, H., D oi, K.: J. Toxocol. Pathol., 14, 247-251 (2001)

59) Tsuda, T., Hamamori, Y., Yamashita, T., Fukumoto, Y., Takai, Y.: FEBS Lett., 208, $39-42$ (1986)

60) Morgan, J.I., Curran, T.: Cell Calcium. 9, 303-311(1988)

61) Cohen, D.R., Curran, T: Crit. Rev. Oncog., 1, 65-88 (1989)

62) Maki, A., Berezesky, I.K., Fargnoli, J., Holbrook, N.J., Trump, B.F.: FASEB J., 6, 919-924 (1992)

63) Yamamoto, N., Smith, M.W., M aki, A., Berezesky, I.K., Trump, B.F.: Kidney Int., 45, 1093-1104 (1994)

64) Yoshino, N., Takizaw, M., Akiba, H., Okumura, H., Tashiro, F., Honda, M., Ueno, Y.: Natural Toxins, 4, 234-241 (1996) 
マウスのリンパ系・造血系組織における T-2トキシン誘発アポトーシス

篠塚淳子 : 東京大学大学院農学生命科学研究科 (113-8657 東京都文京区弥生 1-1-1)

田辺製薬株式会社薬物動態研究所 (335-8505 埼玉県戶田市川岸 2-2-50)

土井邦雄 : 東京大学大学院農学生命科学研究科

T-2 トキシン投与マウスのリンパ系および造血系組織の検索を行い, 帯の病変発現にアポトーシスの関与 が示された、T-2トキシンはリンパ球や造血細胞のような細胞増殖活性の高い細胞に，アポトーシスを誘発 し, 造血系組織の変化はリンパ系組織に先行した .T-2トキシン投与マウスの胸腺ではc-fos mRNA カ持続的 に増加し,アポトーシス誘発は蛋白合成阻害薬の前処置により抑制された . マウス胸腺初代培養系のT-2卜 キシン添加においてもアポトーシスは誘発され, c-fos mRNA の増加か認められた . これらの変化は細胞内 カルシウムイオンキレーターやPKC インヒビター前処置により抑制され，T-2トキシンによるアポトーシ ス誘発に細胞内カルシウムイオン濃度の上昇と c-fosの発現が重要な役割を果たすことが示された .

キーワード : T-2 トキシン, アポトーシス, 胸腺, 脾臓, 骨髄 